\title{
Time evolution of MX-80 bentonite geochemistry under thermo-hydraulic gradients
}

\author{
R. GÓMEZ-ESPINA ${ }^{1}$ AND M.V. VILLAR ${ }^{2, *}$ \\ ${ }^{1}$ Universidad Andres Bello, Carretera Concepción-Talcahuano, 7100 Concepción, Chile \\ ${ }^{2}$ CIEMAT, Avd. Complutense 40, 28040 Madrid, Spain
}

(Received 31 May 2015; revised 1 February 2016; Guest editor: Maarten Van Geet)

\begin{abstract}
ABS TR ACT: Two 20-cm long columns of MX-80 bentonite compacted at a nominal dry density of $1.7 \mathrm{~g} / \mathrm{cm}^{3}$ with a water content of $17 \%$ were tested in thermo-hydraulic (TH) cells with the aim of simulating the conditions of a sealing material in a nuclear waste repository. On top of the columns a hydration surface simulated the host rock supplying groundwater and at the bottom a heater simulated the waste canister. The tests comprised two phases: a heating phase and a 'heating + hydration' phase. The temperatures at the ends of the columns were set during the last phase to $30^{\circ} \mathrm{C}$ at the top and $140^{\circ} \mathrm{C}$ at the bottom, respectively. The thermo-hydraulic treatment resulted in major changes along the bentonite columns. These changes led to significant gradients along the column with respect to the physical state (water content, dry density) and geochemistry of the bentonite. Smectite dissolution processes occurred. As a result, colloids were probably produced, particularly in the more hydrated areas. In the warmest part of the columns precipitation of carbonates took place, caused by their solubility decrease with temperature and the evaporation. The increase in water content reduced the ionic strength of the pore water in the more hydrated areas where species such as gypsum were dissolved. The solubilized ions were transported towards the bottom of the columns; $\mathrm{Na}^{+}, \mathrm{Ca}^{+}, \mathrm{Mg}^{2+}$ and $\mathrm{SO}_{4}^{2-}$ moved at a similar rate and $\mathrm{K}^{+}$and $\mathrm{Cl}^{-}$moved farther. These solubilized ions precipitated in the form of salts farther away along the columns as the test was longer. The TH treatment implied the loss of exchangeable positions in the smectite, particularly towards the heater. The cation exchange complex was also modified.
\end{abstract}

KEYWORDS: bentonite, engineered barriers, nuclear waste, pore water, thermo-hydraulic treatment.

Many countries have developed concepts for the disposal of radioactive waste that rely on its isolation from the environment by using a combination of natural (host rock) and engineered barriers (container, sealing materials). Most of the deep geological repository concepts which are considering the use of bentonite-based sealing materials around the radioactive waste canisters foresee temperatures in the engineered barrier of $<100^{\circ} \mathrm{C}$. The choice of this limit temperature intends to rule out alteration and

*E-mail: mv.villar@ciemat.es

DOI: $10.1180 /$ claymin.2016.051.2.03 degradation processes in the bentonite and guarantee its stability (Wersin et al., 2007). Some doubts exist, however, about the actual significance of this limit, which has a high cost in terms of time of canister cooling before final deposition and size of the repository. Hence, both theoretical studies and reviews (Karnland \& Birgesson, 2006; Wersin et al., 2007) and laboratory and field tests have been undertaken with the aim of assessing the significance of this threshold and its actual consequences for bentonite performance.

Several field tests that applied temperatures of $>100^{\circ} \mathrm{C}$ to a bentonite buffer were performed at the Äspö Hard Rock Laboratory (HRL, Sweden), namely the Long Term Test of Buffer Material (LOT) and the 
Temperature Buffer Test (TBT) experiments. Other recently dismantled field tests performed in Äspö in which the MX- 80 bentonite was subjected to lower temperatures were the Prototype Repository and the Canister Retrieval Test (CRT). All of them were conducted by the Swedish Nuclear Fuel and Waste Management Company (SKB), sometimes in cooperation with other institutions.

In the in situ LOT experiment, heaters were installed in vertical boreholes drilled in the granitic rock. The $10-\mathrm{cm}$ gap between the heater tube and the host rock was filled with blocks of MX-80. In particular, the LOT A0 and A2 parcels were in operation for 1.5 and $6 \mathrm{y}$, respectively, with the heater set to $130^{\circ} \mathrm{C}$. The experimental measurements of these tests were reported by Karnland et al. $(2009,2011)$ and Olsson \& Karland (2011).

The Prototype field test consisted of six deposition holes, each containing a full-scale buffer of compacted MX-80 surrounding a copper canister equipped with heaters. After 8 y of operation the buffer of two deposition holes was retrieved and analysed. The temperature in the buffer had never exceeded $85^{\circ} \mathrm{C}$ and it had been hydrated naturally by the surrounding granite groundwater (Olsson et al., 2013).

In the CRT field experiment a full-size copper canister was surrounded by bentonite blocks in a deposition hole excavated in the granitic bedrock. Before dismantling, this buffer was hydrated artificially with a natural $\mathrm{Na}-\mathrm{Ca}$-Cl-type groundwater for $5 \mathrm{y}$ while the temperature at the canister surface was kept at $95^{\circ} \mathrm{C}$ (Dueck et al., 2011).

The Temperature Buffer Test (TBT project) was a full-scale test for radioactive waste disposal that aimed to improve the understanding of the thermohydro-mechanical behaviour of buffers with a temperature around and above $100^{\circ} \mathrm{C}$ during the water-saturation transient. ANDRA ran this test at the Äspö HRL in cooperation with SKB. Two heaters were stacked in a vertical hole drilled in the granite and surrounded by compacted blocks of MX-80 (Sandén et al., 2007). The distance between the heater surface and the host rock was $51 \mathrm{~cm}$. For $\sim 1700$ days the highest temperature at the heater surface was 135 $145^{\circ} \mathrm{C}$, but during the last 600 days it was close to $160^{\circ} \mathrm{C}$. The bentonite barrier was hydrated artificially from the rock surface with granitic water for 1500 days and then with deionized water. The experiment was dismantled after an operational time of almost 7 y (Åkesson, 2012) and the hydro-mechanical and geochemical characteristics of the bentonite were analysed (Åkesson et al., 2012).
Complementary to the large-scale in situ tests, laboratory thermo-hydraulic $(\mathrm{TH})$ tests reproducing the thermal and hydraulic conditions in the bentonite barrier of a repository can be carried out. The advantages of these tests are that the boundary conditions are better controlled and that they are less costly and easier to perform. Because of their simple configuration they are also very useful for identifying and quantifying processes and for validating numerical models (Villar et al., 2008). To simulate the conditions of the TBT field test in the laboratory, cylindrical blocks of MX-80 were subjected in TH cells to heating and hydration by opposite ends. Two tests were performed and dismantled after 1.4 (TBT500) and 5 y (TBT1500) of operation. Upon dismantling, water content, dry density, physical properties, geochemistry and mineralogy were determined in different positions along the bentonite columns (Gómez-Espina \& Villar, $2010 \mathrm{~b}, 2015)$. This paper analyses jointly the results of the two laboratory tests from the perspective of the evolution of the geochemical and mineralogical changes observed over time. In the Discussion section these results are compared with those obtained in the in situ tests mentioned above.

\section{MATERIALS AND METHODS}

The bentonite MX-80 (Wyoming, USA) was supplied in the form of Na-homogenized powder. The batch used in this work consisted of montmorillonite (92\%), cristobalite $(1 \%)$, quartz $(1 \%)$, feldspars $(5 \%)$ and traces of calcite, gypsum, dolomite, halite and pyrite. The smectitic phase was actually a smectite-illite interstratified with $6-7 \%$ of illite layers. The solid grain density was $2.72 \mathrm{~g} / \mathrm{cm}^{3}$.

The TH tests were performed in cells made of Teflon ${ }^{\circledR}$ (described by Gómez-Espina and Villar, 2010a, 2013), used to prevent lateral heat conduction as much as possible (Fig. 1). The initial internal diameter of the cell was $7 \mathrm{~cm}$ and the inner length was $20 \mathrm{~cm}$, but during the course of the experiments the Teflon ${ }^{\circledR}$ was deformed and the diameter increased slightly (see below). Two 10-cm long cylindrical blocks of MX-80 compacted with a nominal water content of $17 \%$ at a target dry density of $1.70 \mathrm{~g} / \mathrm{cm}^{3}$ were stacked inside the cell. The material was prepared in two blocks because of the difficulty in compacting uniaxially a single $20 \mathrm{~cm}$-long block, which would, in addition, have a significant density gradient along it. Furthermore, the joint between the two blocks mimicked those between blocks in the actual barrier. The bottom part of the cell was a planar stainless steel 


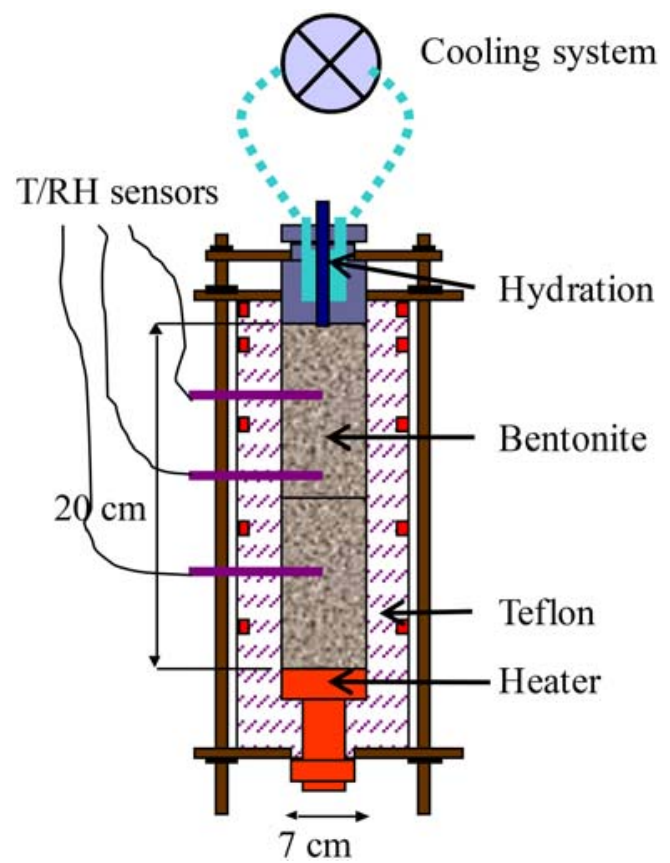

FIG. 1. Schematic design of the thermo-hydraulic cells.

heater. The hydration took place through the upper plug. Deionized water taken from a deposit placed $80 \mathrm{~cm}$ above the top of the cell was used. A cooling system was installed on top of the cells to maintain a constant temperature of $30^{\circ} \mathrm{C}$. The column was instrumented with three capacitive sensors that measured relative humidity and temperature inside the bentonite during the tests.

The tests started with a heating phase in which the heater temperature was increased progressively up to $140^{\circ} \mathrm{C}$, in 8 days in the case of test TBT500 and in 202 days in the case of test TBT1500. The total duration of the heating phase was 28 days for test TBT500 and 321 days for test TBT1500. After this period, hydration started from the top of the columns while the heating was maintained. This "heating + hydration" phase continued for 496 and 1510 days more, respectively. Although in the large-scale field test natural hydration occurred from the moment the buffer was installed and was already taking place when heating started, in the laboratory tests the two processes were initially separated in order to be able to tell apart the effects of heating and of hydration on the bentonite temperature and humidity evolution.

At the end of the $\mathrm{TH}$ treatment, the cells were dismantled and the clay blocks were extracted. Once extracted, the bentonite columns were cut into ten cylindrical sections, $2 \mathrm{~cm}$ thick, and used for the different analyses. Water content, dry density, specific surface area, porosity and basal spacings were also determined and the results are reported in detail elsewhere (Villar et al., 2012; Gómez-Espina \& Villar, 2010a, 2013). For the postmortem determinations reported here, the following methods were used (Gómez-Espina \& Villar, 2013): (1) The gravimetric water content was determined in duplicate for each sample by oven drying them at $110^{\circ} \mathrm{C}$ for $48 \mathrm{~h}$. To calculate the dry density, the volume of the specimens was determined by immersing them in a recipient containing mercury and by weighing the mercury displaced. (2) X-ray diffraction (XRD) patterns were obtained from random powders and in oriented aggregates of the $<2 \mu \mathrm{m}$ size fraction and from the size fraction of between 2 and $20 \mu \mathrm{m}$. The powders were obtained by grinding the samples to a size of $<53 \mu \mathrm{m}$ after having dried them at $65^{\circ} \mathrm{C}$ for $24 \mathrm{~h}$. The small fractions were obtained by dispersion and sedimentation in deionized water. (3) Two different procedures were used to determine the content of soluble salts in duplicates (test TBT1500) or triplicates (test TBT500) of each section: (i) SS1: aqueous extracts with a solid/liquid ratio of 1:8 were prepared by dispersing $5 \mathrm{~g}$ of ground, oven-dried sample in $40 \mathrm{~mL}$ of deionized water. After $24 \mathrm{~h}$ of agitation, centrifugation at $15,500 \mathrm{rpm}$ and filtration by $0.45 \mu \mathrm{m}$, the $\mathrm{pH}$ and the electrical conductivity of the aqueous extract were measured. The ions in the extract were measured using a chromatograph with a detection limit of $0.1 \mathrm{ppm}$. The carbonate and bicarbonate content in test TBT1500 was computed as total alkalinity, assuming it as the balance difference between anions and cations. In test TBT500 the alkalinity was measured by potentiometric titration. (ii) SS2: aqueous extracts with a solid/liquid ratio of 1:16 were prepared by dispersing $2.5 \mathrm{~g}$ of ground, air-dried sample in $40 \mathrm{~mL}$ of deionized water. The mixtures were agitated for $48 \mathrm{~h}$, centrifuged at 15,500 rpm and filtered through a $0.22 \mu \mathrm{m}$ cellulose membrane. The extracts were analysed by inductively coupled plasma mass spectrometry (ICP-MS) for cations and by ionic chromatography for anions. $\mathrm{Na}$ and $\mathrm{K}$ contents were determined by flame spectrophotometry. The alkalinity was measured by potentiometric titration. (4) To determine the cation exchange capacity (CEC), the exchange sites of the smectite were saturated with a Cu-trien complex (Meier \& Kahr, 1999). The variations in the absorbance of the aqueous extracts, measured by spectrophotometry, with respect to the 
absorbance in the initial Cu-trien solution, gave the CEC value. Duplicates from every section were prepared and analysed. (5) Two procedures were used to determine the exchangeable cations in duplicate for each sample: (i) EC1: The exchangeable cations were analysed in aqueous extracts obtained by adding to the MX-80 a $0.5 \mathrm{~N}$ solution of $\mathrm{CsNO}_{3}$ with a solid/liquid ratio of 1:8. The cation content was determined by chromatography. (ii) EC2: the aqueous extracts were prepared by adding to the bentonite a $0.5 \mathrm{~N}$ solution of $\mathrm{CsNO}_{3}$ with a solid/ liquid ratio of $1: 16$. The $\mathrm{pH}$ of the solution was fixed to 8.2 to avoid the dissolution of carbonates. $\mathrm{Na}$ and $\mathrm{K}$ were measured using flame spectrophotometry and the remaining cations using ICP-MS.

\section{RESULTS}

During the initial heating phase the sensors placed inside the bentonite recorded a quick stabilization of temperature in response to the heater-temperature changes. Water vapour moved away from the heater, but because of the initially high water saturation of the bentonite and its low permeability, the attainment of the hydraulic equilibrium took a very long time, about 300 days in test TBT1500. In fact, when hydration started in test TBT500 there was no hydraulic equilibrium along the column. Besides, because the heating phase was much shorter in test TBT500 (28 vs. 321 days), the initial drying of the bentonite close to the heater was not very intense in this test, whereas at the end of the heating phase the lower half of column TBT1500 had relative humidity which was less than the initial one $(41 \%$ vs. $73 \%)$. The beginning of hydration did not mean any major change in the temperature distribution within the MX-80; the relative

TABLE 1. Initial and final characteristics of the TH tests.

\begin{tabular}{lll}
\hline Test & TBT500 & TBT1500 \\
\hline Initial $w(\%)$ & 15.8 & 16.9 \\
Initial $\rho_{\mathrm{d}}\left(\mathrm{g} / \mathrm{cm}^{3}\right)$ & 1.72 & 1.69 \\
$\begin{array}{l}\text { Duration of heating phase (days) } \\
\text { Duration of heating + hydration }\end{array}$ & 28 & 321 \\
$\quad$ phase (days) & 156 & 1510 \\
$\begin{array}{l}\text { Final average } w(\%) \\
\text { Final }^{1} \rho_{\mathrm{d}}\left(\mathrm{g} / \mathrm{cm}^{3}\right)\end{array}$ & 18.4 & 23.0 \\
\hline
\end{tabular}

\footnotetext{
${ }^{1}$ the change in dry density was caused by the deformation
} of the Teflon cell during the TH tests. humidity tended to increase at all locations, however (Gómez-Espina \& Villar, 2015).

At the end of the 'heating + hydration' phase the cells were dismantled and the bentonite columns were extracted. The joint between the two blocks that constituted the column in test TBT1500 was sealed as a consequence of the water content increase, but at the end of test TBT500 the two blocks were still separate. The initial and final characteristics of the tests are shown in Table 1, where $w$ stands for water content and $\rho_{\mathrm{d}}$, for dry density. The final dry densities were less than the initial densities due to the expansion of the MX-80 on saturation, which was allowed by the Teflon ${ }^{\circledR}$ cell deformation. This means that the bentonite was able to develop swelling pressure against the cell wall. Because the longest test reached greater water content, the swelling was also higher and the final average dry density was less. The columns were subsampled in ten $2 \mathrm{~cm}$-thick cylindrical sections in which water content and dry density were determined. A sharp water-content gradient was observed along the columns, as well as a dry density gradient. In the part of the columns where the water content had increased because of hydration, swelling occurred and the dry density of the bentonite decreased. Conversely, in the areas which were dried by the effect of heating, the water content decreased below the initial one and the dry density increased, because of the bentonite shrinkage caused by drying and of the contraction caused by the expanding wet bentonite. Note that no cracks were observed upon dismantling indicating that the dry bentonite experienced an overall contraction. The final water contents along the bentonite columns in the two tests and the steady temperatures along the columns during the tests are shown in Fig. 2. The thermal gradient close to the heater was very steep, and the heat losses through the bottom and walls of the cells were significant. The relation between high temperature and intense drying was highlighted here. Upon dismantling, the o-rings at the bottom of the cells were seen to be damaged; the vapour phase might escape during the tests, therefore contributing to the intense drying of the bentonite closest to the heater.

\section{Mineralogy}

The mineral phases identified in the XRD patterns of the powder samples were assessed semi-quantitatively by measuring the area of the diagnostic peak of each mineral and correcting it by taking into account the reflecting factors (Moore and Reynolds, 1997). The 
TABLE 2. Ionic balance in the two laboratory tests (an upward/downward arrow indicates that the concentration was greater/smaller than in the original sample; two arrows indicate that the change was greater than in the other test).

\begin{tabular}{lcclcc}
\hline Exchangeable cations & TBT500 & TBT1500 & Soluble salts & TBT500 & TBT1500 \\
\hline $\mathrm{Na}^{+}$ & $\downarrow$ & $\downarrow \downarrow$ & $\mathrm{Na}^{+}$ & $\uparrow$ & $\uparrow \uparrow$ \\
$\mathrm{K}^{+}$ & $\downarrow$ & $\downarrow \downarrow$ & $\mathrm{K}^{+}$ & $\uparrow$ & $\uparrow$ \\
$\mathrm{Ca}^{2+}$ & $\uparrow$ & $\uparrow \uparrow$ & $\mathrm{Ca}^{2+}$ & $\downarrow$ & $\uparrow$ \\
$\mathrm{Mg}^{2+}$ & $\downarrow$ & $\downarrow$ & $\mathrm{Mg}^{2+}$ & $\downarrow$ & $\uparrow$ \\
& & & $\mathrm{Cl}^{-}$ & $\uparrow \uparrow$ & $\uparrow$ \\
& & & $\mathrm{SO}_{4}^{2-}$ & $\uparrow$ & $\uparrow$ \\
& & & Alkalinity & $\downarrow \downarrow$ & $\downarrow$ \\
\hline
\end{tabular}

results for column TBT500 presented previously by Gómez-Espina \& Villar (2010a,b) were reprocessed following the same systematic procedure as for column TBT1500. An overall decrease in the smectite content with respect to the initial value took place, especially in the most hydrated areas and in the longer test (Fig. 3). On the other hand, the overall contents of cristobalite, quartz, feldspars and calcite increased. These were probably relative increases caused by the decrease in the smectite content, because proportions of each mineral were recalculated in order to sum to $100 \%$. The calcite increase, which seemed to be particularly sharp at $3 \mathrm{~cm}$ from the heater in test TBT1500, could have been caused by the increase in the system temperature which reduces calcite solubility.

In the XRD traces, the $d$ spacings of the 060 reflections increased towards the heater indicating an increase in the $\mathrm{Mg}$ content of the octahedral sheet (Grim and Kulbicki, 1961). This effect was more significant in the longer test.

The $d_{001}$ reflection of the glycolated oriented aggregates showed values in the original sample of

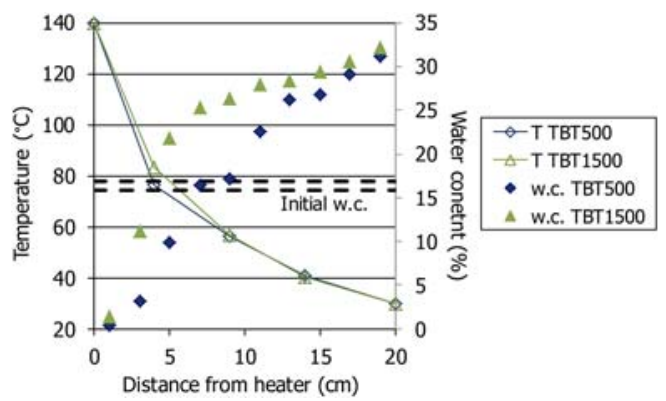

FIG. 2. Steady temperatures and final water content of the bentonite along the columns.
$1.703 \mathrm{~nm}$ that were maintained after the $\mathrm{TH}$ tests, except in the middle part of the columns, where it decreased to values close to $1.640 \mathrm{~nm}$. This is an indication of the preservation of the smectite swelling ability. Quantification of the amount of illite in the mixed layers was performed by applying the Reynolds (1980) method to the glycolated oriented aggregates of the samples. The results obtained for the two columns and the original material are shown in Fig. 4. In the original material the amount of interstratified illite was greater in the finest fraction. Besides, the TH treatment led to this amount being increased significantly in the upper half of the column of the longer test.

\section{Soluble salts (aqueous extracts)}

The amount of soluble salts was determined by performing aqueous extracts following two different procedures, SS1 and SS2. Method SS2 consisted of an intense acidification that resulted in the dissolution of smectite colloidal particles present in the aqueous extracts, and resulted in higher concentrations of $\mathrm{Mg}$ and the presence of $\mathrm{Si}, \mathrm{Al}$ and $\mathrm{Fe}$ in the aqueous extracts (Gómez-Espina \& Villar, 2013, 2015). For the sake of clarity only the results obtained with method SS1 are presented here.

The amount of soluble salts measured in the aqueous extracts increased with respect to the original content in the two tests, except in the $5 \mathrm{~cm}$ closest to the hydration surface. The overall increase in soluble-salt content was of $22 \%$ in test TBT1500 and of $15 \%$ in test TBT500. It was particularly high at $9 \mathrm{~cm}$ from the heater in the shorter test and at $5 \mathrm{~cm}$ from the heater in the longer one.

The main cation in the aqueous extracts was $\mathrm{Na}^{+}$and the major anion was $\mathrm{SO}_{4}^{2-}$. The distribution of these 

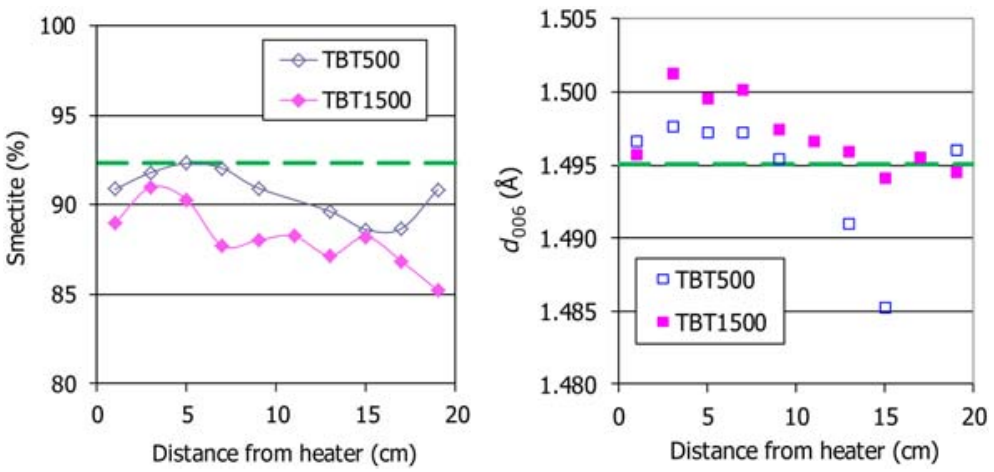

FIG. 3. Smectite content and $d_{060}$ spacing along the columns and in the original material (dashed lines) as determined by XRD.

ions along the columns followed the patterns described in the previous paragraph for the overall soluble salt content (Fig. 5). The concentrations of $\mathrm{Ca}$ and $\mathrm{Mg}$ changed along the columns following similar patterns to those of $\mathrm{Na}$ and sulfate. The amounts of all these ions also increased slightly when in contact with the heater. The distribution of $\mathrm{Cl}^{-}$along the columns was different, because it was concentrated mainly at $3 \mathrm{~cm}$ from the heater in the two tests (Fig. 6). The final average content in the aqueous extracts of all these ions was greater than in the original material, except for $\mathrm{Ca}$ and $\mathrm{Mg}$ in test TBT500.

Both the $\mathrm{pH}$ and the alkalinity of the aqueous extracts after the $\mathrm{TH}$ tests were smaller, on average, than in the original material. The more pronounced

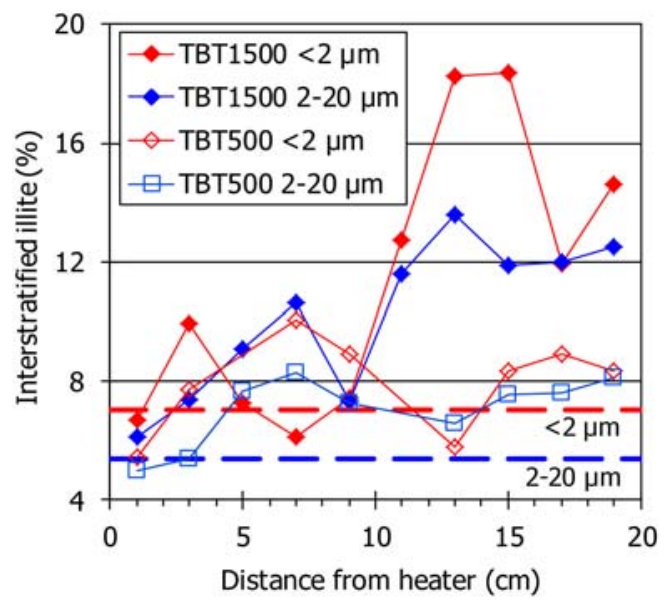

FIG. 4. Interstratified illite content along the columns and in the original material (dashed lines) as determined in the glycolated aggregates of two clay fractions. decrease took place at $7-10 \mathrm{~cm}$ from the heater in test TBT500 and at $5 \mathrm{~cm}$ from the heater in test TBT1500. From these low-pH areas, the $\mathrm{pH}$ increased in both tests towards the heater and towards the hydration surface, particularly in the longer test. In particular, the $\mathrm{pH}$ and the alkalinity close to the hydration surface were above the initial values in test TBT1500 (Fig. 7).

\section{Pore-water modelling}

The composition of the pore water was deduced through geochemical modelling from the aqueousextracts results following the methodology described by Gómez-Espina \& Villar (2010a, 2013, 2015). This included correcting the ion concentrations measured in the aqueous extracts (with method SS1) by computing the concentration of each ion in the pore water according to the actual solid:liquid ratio in each sample during the $\mathrm{TH}$ test, taking into account the dry density and water content in each section. The concentrations obtained were very high for all ions, for which reason the theoretical solution would be oversaturated with respect to several potential mineral phases. To calculate the actual ion concentration in this oversaturated pore solution, the geochemical modelling software PHREEQC (Parkhurst \& Appelo, 1999) was used, with the database llnl.dat, recommended for high temperatures. This database uses activity coefficients computed with the Debye-Hückel equation, which is not entirely correct for high-salinity values (Appelo, 2015). The llnl.dat database includes elements such as $\mathrm{Al}$ and $\mathrm{Si}$, however, which are fundamental when dealing with clay systems and are not included in other databases more suitable for high salinities. The actual temperatures during the test in 

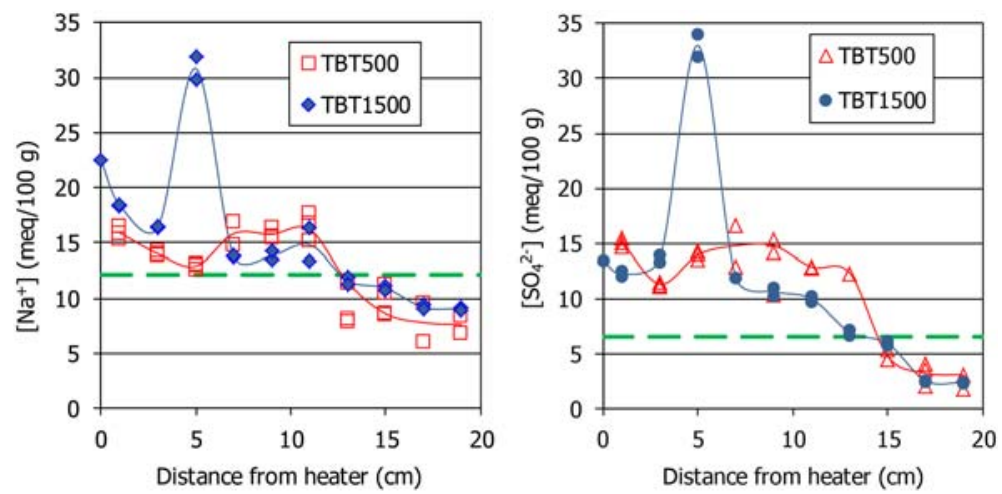

FIG. 5. Na and $\mathrm{SO}_{4}^{2-}$ concentrations in the aqueous extracts of samples of the two TH tests and of the original material (dashed lines).

each section (Fig. 2) were taken into account to select the equilibrium constant for each mineral phase, whereas a $\mathrm{pH}$ value of 8 was used for all the sections. The results obtained are plotted in Fig. 8. The difference between the concentrations measured in the aqueous extracts (once corrected) and computed for the pore water would have been caused by the dilution of soluble salts during the aqueous-extract preparation process.

Because of the dissolution of low-solubility species and of the loss of exchangeable positions in the smectite, the amount of soluble salts in the pore water increased with respect to the original value in the more

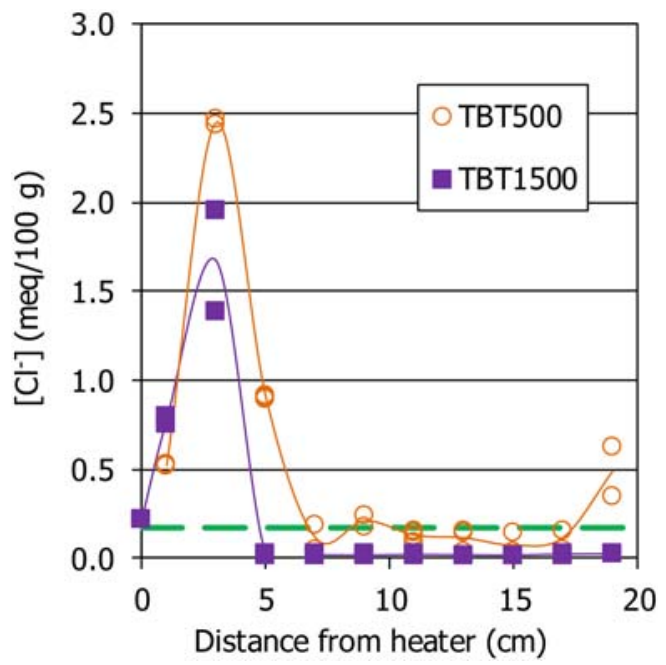

FIG. 6. $\mathrm{Cl}^{-}$concentration in the aqueous extracts of samples of the two TH tests and of the original material (dashed line). hydrated areas and in the longer test. The increase in water content caused the pore water to be more diluted after the TH tests, however, and its ionic strength decreased with respect to the original, particularly in the longer test in which the water content was greater. Only in the $3 \mathrm{~cm}$ closest to the heater was the ionic strength of the pore water greater than the initial pore water, because of the evaporation and water loss (Fig. 9).

The concentrations of $\mathrm{Na}, \mathrm{Ca}, \mathrm{Mg}$ and sulfate, as well as the alkalinity decreased towards the heater. The

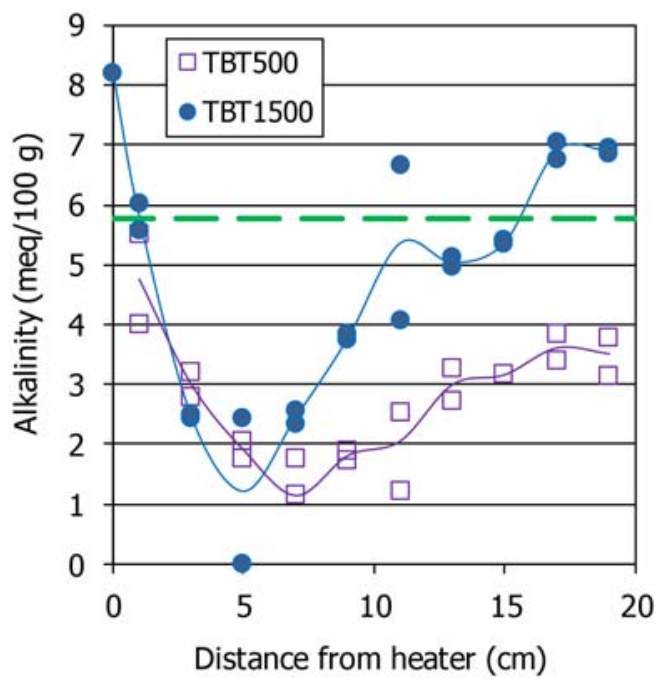

FIG. 7. Alkalinity of the aqueous extracts of samples of the two TH tests and of the original material (calculated as sum of carbonates and bicarbonates for test TBT500 and as difference between cations and anions in test TBT1500). 


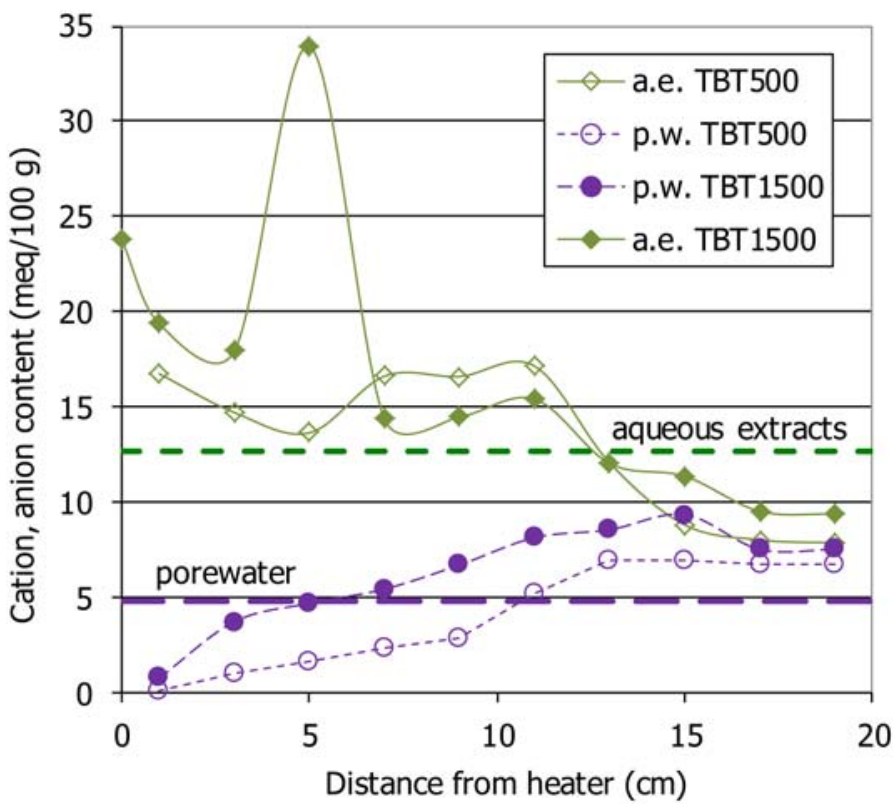

FIG. 8. Ion content along the bentonite columns and in the original material (dashed lines) as measured in the aqueous extracts (a.e.) and computed using PHREEQC in the pore water (p.w.)

overall sulfate content increased in the pore water, especially in the longer test and the distribution along the columns followed the same pattern as for $\mathrm{Na}$, decreasing towards the heater (Fig. 10) indicating that near the heater the pore water would be in equilibrium with thenardite $\left(\mathrm{Na}_{2} \mathrm{SO}_{4}\right)$. On the other hand, the

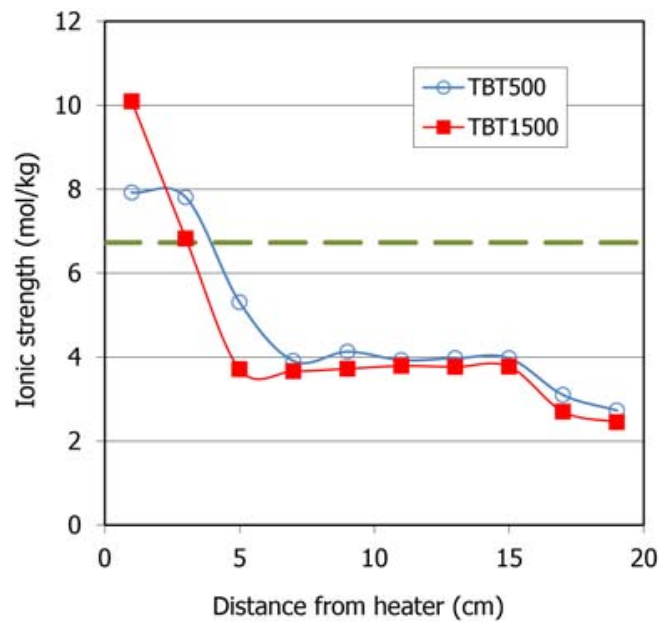

FIG. 9. Modelled ionic strength of the pore water along the bentonite columns and in the original material (dashed line). alkalinity decreased significantly with respect to the original material in both tests, particularly in the shorter one (Fig. 11). The distribution of Ca seemed to be coupled to the alkalinity.

Chloride behaved as a conservative ion and moved with the water front, concentrating at $3 \mathrm{~cm}$ from the

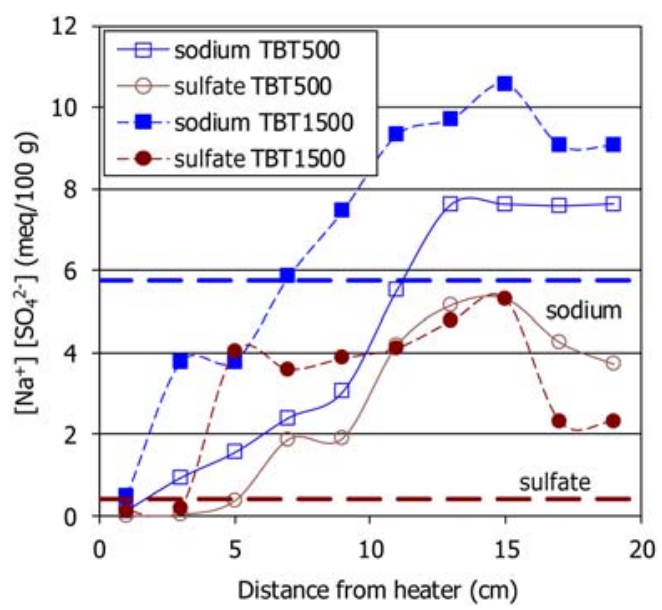

FIG. 10. Calculated alkalinity of the pore water along the bentonite columns and in the original material (dashed line). 


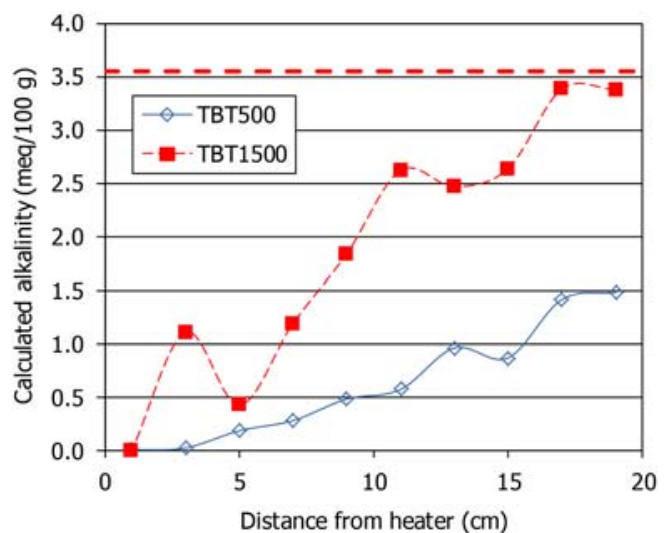

FIG. 11. Calculated concentration of $\mathrm{Na}$ and $\mathrm{SO}_{4}^{2-}$ in the pore water along the bentonite columns and in the original material (dashed line).

heater in the longer test and at $5 \mathrm{~cm}$ from the heater in test TBT500 (Fig. 12). The chloride content decreased close to the heater because of its equilibrium with halite. Otherwise, the $\mathrm{Cl}^{-}$and $\mathrm{Na}^{+}$concentrations in the pore water obtained by modelling were the same as those measured in the aqueous extracts, because their concentrations were below saturation for any soluble salt. The $\mathrm{Mg}$ concentration in the pore water of test TBT1500 was also the same as in the aqueous extracts, i.e. below saturation.

According to the modelling, the soluble salts in the solid phase and in equilibrium with the pore water would be $\mathrm{Na}$ and $\mathrm{Ca}$ sulfates, specifically gypsum in

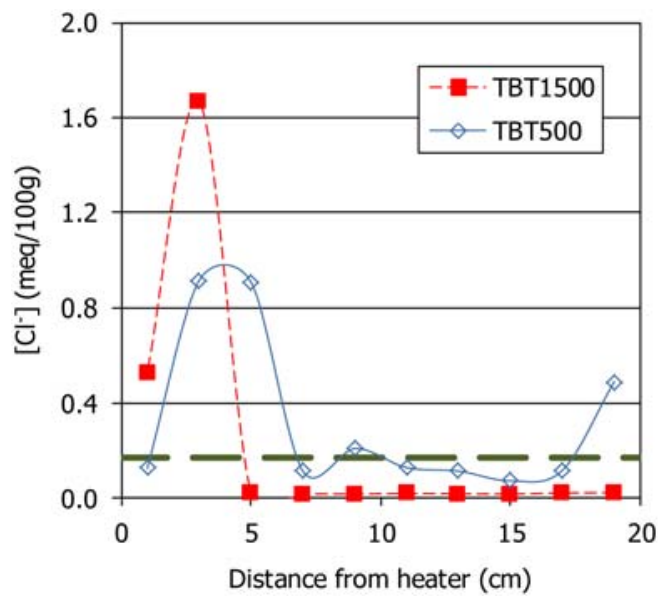

FIG. 12. Calculated concentration of chloride in the pore water along the bentonite columns and in the original material (dashed line). the more hydrated area and glauberite $\left(\mathrm{Na}_{2} \mathrm{Ca}\left(\mathrm{SO}_{4}\right)_{2}\right)$ in the central areas of the columns. Thenardite precipitation would control the equilibrium with $\mathrm{Na}$. In the drier bentonite the equilibrium would be controlled by thenardite and halite in test TBT500 and by thenardite and anhydrite in test TBT1500.

Overall the pore water evolved from $\mathrm{Na}$ bicarbonate type to $\mathrm{Na}$ sulfate type in the hydrated areas and to $\mathrm{NaCa}$ type close to the heater, because of the low degree of water saturation.

\section{Cation exchange capacity and exchangeable cations}

The CEC and the composition of the exchangeable complex were determined in duplicates of the ten sections defined at the end of the TH tests. The average CEC value obtained for the whole column in test TBT1500 was $60.6 \mathrm{mmol} / 100 \mathrm{~g}$ and in test TBT500, $56.2 \mathrm{mmol} / 100 \mathrm{~g}$, which are less than the original value for MX-80 (64.2 mmol/100 g). The loss in exchange capacity was particularly significant close to the heater. The sum of exchangeable cations also reflected this loss in exchangeable positions and the trend to decrease towards the heater.

The cation exchange complex was also modified as a consequence of the TH treatment. The exchangeable cations were determined in duplicate for each sample following the procedures EC1 and EC2. The results obtained with the two methods were coherent and showed the same patterns, except for Ca (GómezEspina \& Villar, 2013, 2015). The average amount of exchangeable $\mathrm{Na}$ and $\mathrm{Mg}$ along the columns was lower than in the original material. Moreover, the amount of exchangeable $\mathrm{Na}$ decreased in both tests towards the heater - more significantly in the longer test - whereas the overall amount of exchangeable $\mathrm{Mg}$ increased in the longer test, mainly at $3 \mathrm{~cm}$ from the heater (for the sake of clarity in Fig. 14, only the results obtained using method $\mathrm{EC} 1$ are shown). The average Ca content in the interlayer also increased slightly over time; hence the final average value was greater in test TBT1500. For this cation the two methods gave notably different results in absolute terms, although the trends along the columns were similar, with a decrease in exchangeable Ca near the hydration surface and an increase at $\sim 5 \mathrm{~cm}$ from the heater, more acute in the longer test (Fig. 15).

\section{DISCUSSION}

The two laboratory tests reported here simulated the conditions of the bentonite barrier in a radioactive 


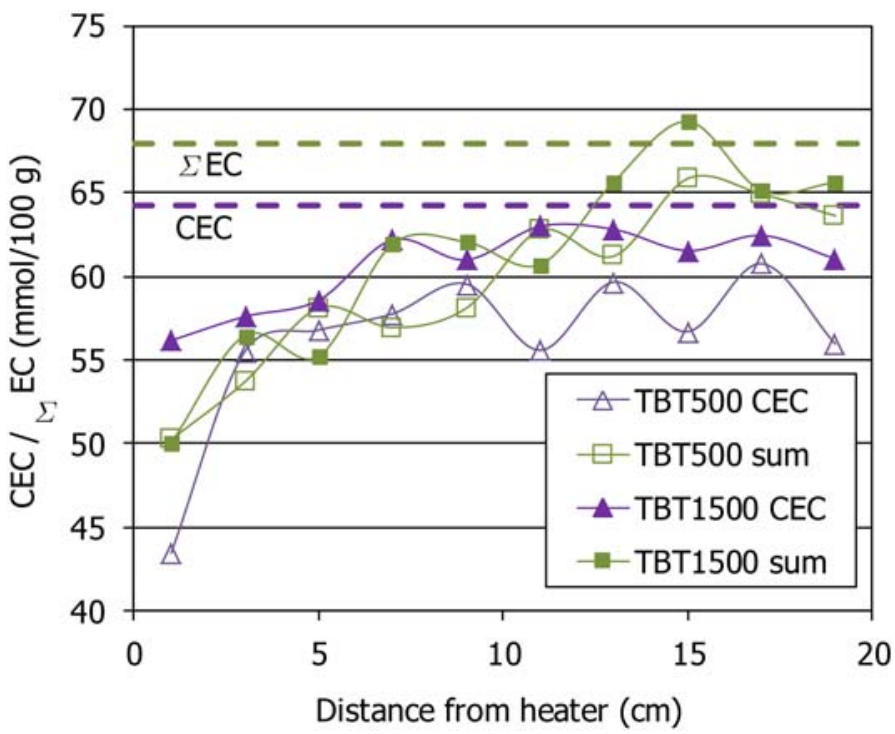

FIG. 13. Cation exchange capacity (CEC) and sum of exchangeable cations $(\Sigma \mathrm{EC})$ along the bentonite columns and in the original material (dashed lines).

waste repository and thus were performed in cylindrical cells in which a column of compacted bentonite was heated to $140^{\circ} \mathrm{C}$ through the bottom and hydrated through the upper surface. In particular they reproduced the conditions of the bentonite in the TBT field test, although deionized water was used to saturate the bentonite instead of the Äspö granitic groundwater.
Other dissimilarities between these tests and the real case were that, because of the cell configuration, the thermal gradient was greater in the lab tests than it would be in the real repository and that evaporation from the bottom of the column tests was allowed. The differences between the two lab tests were: the heating phase was shorter in test TBT500 than in test

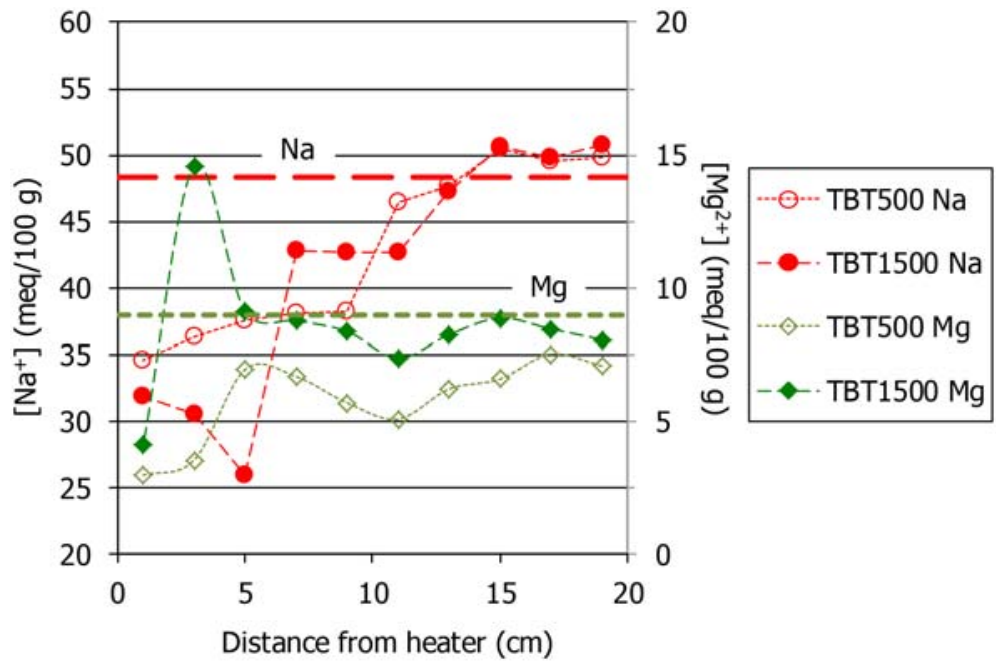

FIG. 14. Na and $\mathrm{Mg}$ concentration in the exchange complex after the TH tests and in the original material (dashed lines), as determined using method EC1. 


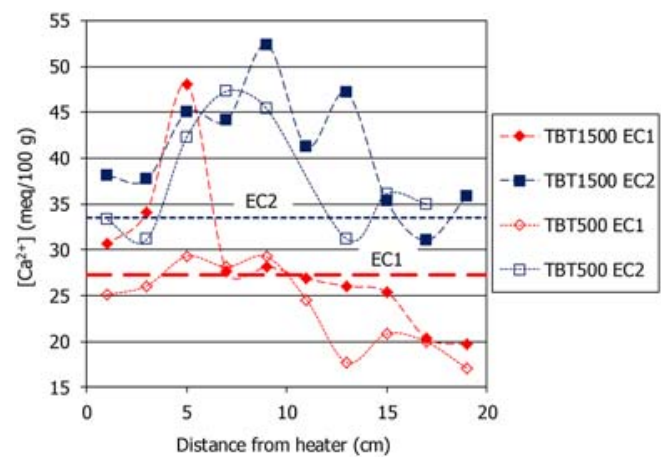

Fig. 15. Ca concentration in the exchange complex after the TH tests and in the original material (dashed lines), as determined with methods $\mathrm{EC} 1$ and $\mathrm{EC} 2$.

TBT1500 (28vs. 321 days); and that the duration of the 'heating + hydration' phases was 496 and 1510 days, respectively.

At the end of the tests, water content and dry-density gradients along the bentonite columns were observed. Besides, the overall dry density of the columns had decreased because of the deformation of the Teflon ${ }^{\circledR}$ cells; more significantly in the longer test, because the water content and consequently the swelling, were greater. The water content in the vicinity of the heater was very small in both tests. The postmortem measurements after dismantling of the TBT field test, which lasted almost $7 \mathrm{y}$, showed that the degree of saturation was $>94 \%$ even close to the heater ( $\AA$ kesson, 2012). Also, in parcels A0 and A2 of the LOT in situ test, both the experimental measurements (Karnland et al., 2009, 2011) and the modelling (Salas et al., 2014) showed that, although the initial drying in the proximity of the heater was very intense, in $\sim 1 \mathrm{y}$ the whole bentonite barrier was almost fully saturated, meaning that the groundwater pressure exceeded the vapour pressure. In the tests reported here, even after $4 \mathrm{y}$ of testing the water content in the vicinity of the heater remained close to $0 \%$, which is probably due to the vapour leak through the bottom of the cells. This is an experimental particularity of these laboratory tests and does not reproduce the actual conditions in a repository in which evaporation outside the system is not possible and the vapour phase can only move towards the cooler parts of the system. Additionally, the water-injection pressure was very low in the laboratory tests and was probably not able to counteract the vapour pressure. As a consequence, in the tests reported here, the bentonite close to the heater remained drier for longer than in most real repository cases. On the contrary, the temperatures in the rest of the bentonite columns were lower than those in the in situ test because of the different geometry of lab and field tests (axial vs. radial) and the heat losses through the different cell components. The bentonite barrier in the TBT field test was subjected to temperatures of between 140 and $70^{\circ} \mathrm{C}$ and, $20 \mathrm{~cm}$ away from the heater (the length of the test columns), was $\sim 100^{\circ} \mathrm{C}$ (see Fig. 2 for comparison). This might have a certain influence on the geochemical processes observed and discussed below, because the solubility of the ionic species and the diffusion coefficients of ions depend on temperature.

Another major difference between the in situ experiments mentioned and the laboratory tests was the kind of saturation water which was saline in the in situ tests (Äspö groundwater) and deionized in the laboratory tests, and consequently more aggressive in terms of dissolution capacity.

With respect to the changes in the mineralogy of the bentonite, a decrease in the smectite content and an increase of $\mathrm{Mg}$ in the octahedral sheet of the smectite over time, particularly towards the heater, were observed. In addition, the amount of interstratified illite increased towards the hydration area, more noticeably in the longer test. This increment could have been caused by a process of colloidal dissolution which would have affected the smectite layers but not the interstratified illite (Gómez-Espina \& Villar, 2015). The characterization performed by Karnland et al. (2009) of the bentonite used in the LOT A2 test acknowledged the existence of only $1-1.5 \%$ of interstratified illite and no mineralogical changes or structural changes in the montmorillonite after 6 y of treatment, however (as detected by XRD by different laboratories). The post-mortem analysis of the samples retrieved during the dismantling of the TBT field test provided no evidence of any structural changes in the montmorillonite (Åkesson et al., 2012) and they were not observed in the bentonite recovered from the Protoype test (Olsson et al., 2013; Dohrmann \& Kaufhold, 2014).

The particularly sharp calcite increase at $3 \mathrm{~cm}$ from the heater in test TBT 1500 could have been caused by the high temperature and by the increase in concentration of other soluble species in the area. Both factors would decrease the calcite solubility. In addition, the alkalinity of the aqueous extracts reached the lowest values in this area.

Of the two methods used for the determination of soluble salts in aqueous extracts, method SS2 gave systematically an increase in the average final contents 
of $\mathrm{Al}, \mathrm{Fe}, \mathrm{Si}$ and $\mathrm{Mg}$ with respect to the original sample, particularly towards the more hydrated upper part of the columns and in the longer test. As discussed by Gómez-Espina \& Villar (2013, 2015), the reason for these high concentrations could be the detection of colloidal particles in the measurements performed with method SS2, because of the more intense acidulation used for preparation of the samples prior to analysis. Karnland et al. (2009) observed these cations in aqueous leachates of bentonite and suggested as their source ultra-fine clay particles not removed from the solution. These colloidal particles, which should be present in the aqueous extracts prepared both with method SS1 and SS2, although not detected in the first case, would come from the dissolution of smectite during the TH treatment, favoured by the increase in water content and by the fact that the hydration water was deionized. The colloid concentration was computed in an approximate way taking into account the $\mathrm{Al}$ and $\mathrm{Fe}$ concentrations in the aqueous extracts and the amounts of these elements in the structural formula of the smectite. The colloid concentration seems to be related to the water content of the bentonite, increasing with it and consequently with the duration of the test (Fig. 16). There also seems to be a kinetic control on the colloidal dissolution process, as, for similar water contents in the upper part of the columns ( $28 \%)$, the computed number of colloids was much greater in the longer test. The spatial distribution does not point to the movement of colloids as a process taking place in the system. In the longer test and in the $5 \mathrm{~cm}$ nearest to the heater, where the bentonite was thoroughly dried and maintained at a high temperature, the ability to

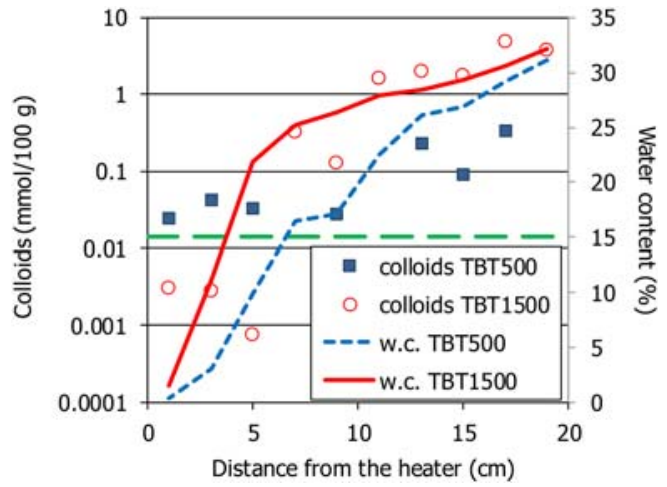

FIG. 16. Computed colloid concentration along the bentonite columns and in the original material (dashed line) and water content (w.c.) measured at the end of the tests. form colloids seems to be lost, perhaps because the salinity of any remaining pore water was too high for colloids to be stable. This dried bentonite, however, showed no less swelling ability upon glycolation (Villar et al., 2012).

The aqueous extracts give no information on the composition of the pore water, but just on the total amounts of soluble salts, which can be precipitated or dissolved in the pore water. To estimate the composition of the pore water it is necessary to model the aqueous-extracts results taking into account the water content, porosity and temperature of the bentonite and the solubility constant of each ion (section on Porewater modelling). According to the pore-water modelling, in test TBT500 the overall amount of ionic species in the pore water was $25 \%$ lower than in the original material (although it was greater in the more hydrated areas, Fig. 8). This could indicate that in the first phases of the test, salt precipitation predominated, probably caused by the drop in alkalinity. Subsequently, in test TBT1500 there was an increase of $\sim 30 \%$ in the amounts of ions in the pore water, which would have been caused by the dissolution produced by the water-content increase.

The progressive hydration eventually led to the dissolution of soluble species, particularly Ca-sulfates in the coldest part of the columns (Karnland et al., 2009; Salas et al., 2014), and the overall increase in ions in the pore water. The loss of exchangeable positions in the interlayer of the smectite (Fig. 13) may have contributed to the increase in soluble species. It is acknowledged that during water saturation of the bentonite, advection plays an important role in the transport of solutes (Fernández \& Villar, 2010; Salas et al., 2014). Thus, many of the solubilized ions moved along the columns with the hydration front which caused the ion concentration in the pore water of the more hydrated bentonite (i.e. top of the columns) to decrease, as shown by the ionic strength spatial distribution pattern (Fig. 9). Some of these ions might have precipitated downwards along the columns, as the difference between aqueous extracts and modelled pore-water concentrations indicate (Fig. 8). This difference has been calculated and plotted in Fig. 17, along with the final water contents for both tests. In test TBT500 the major precipitation must have taken place in the region between 7 and $12 \mathrm{~cm}$ from the heater, whereas in the longer test it took place at $5 \mathrm{~cm}$ from the heater. Indeed, the precipitation of soluble salts requires not only large ion contents in the pore water, but also small water contents (i.e. significant ionic concentration). In this sense, the ionic 

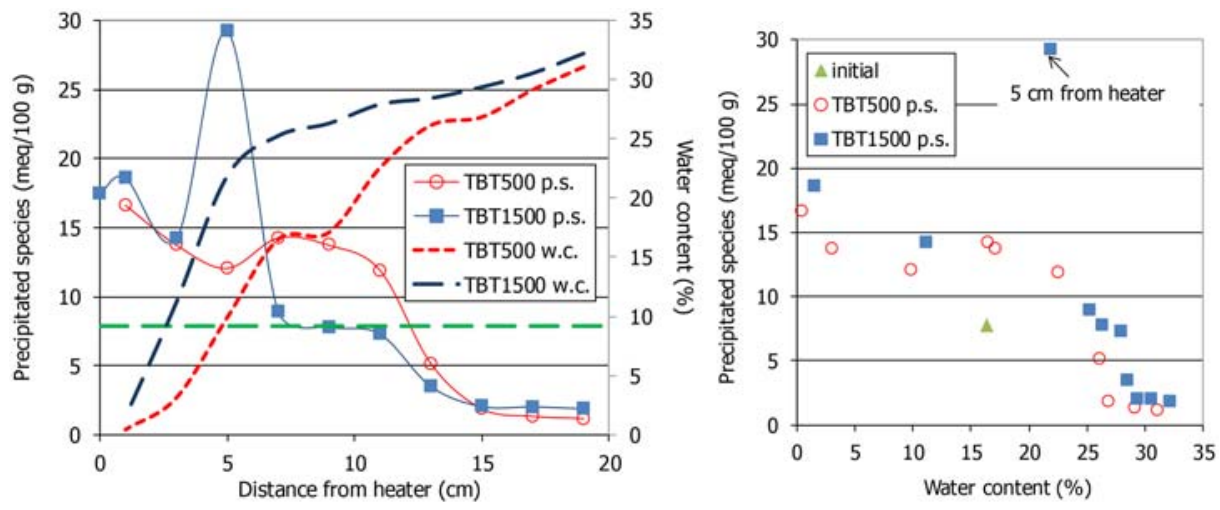

FIG. 17. Water content (w.c.) and ionic species precipitated (p.s.) along the columns estimated from the difference in ion content in the aqueous extracts and in the pore water. Dashed line: original amount of precipitated species.

strength near the heater would be less if evaporation had not been allowed through the bottom of the cells. The region of the TBT500 column in which the precipitated salt content would be below the original one was in the $7 \mathrm{~cm}$ closest to the hydration surface, where the water content was $>25 \%$. In test TBT 1500 the amount of salts precipitated would be similar to or less than that found initially in the $13 \mathrm{~cm}$ closest to the hydration surface, in which the water content was very large. The species precipitated would be $\mathrm{Na}, \mathrm{Ca}$ and $\mathrm{Mg}$ sulfates. In tests TBT1500, anhydrite would precipitate near the heater because of the large increase in soluble Ca content (not observed in test TBT500) and its solubility decrease with temperature. Anhydrite was observed to accumulate at some distance from the heater in the TBT field test ( $\AA$ kesson et al., 2012) and also in the warmer parts of the LOT A2 parcel (Olsson \& Karnland, 2011) and of the CRT (Dueck et al., 2011). The computed chloride content in the pore water was below saturation at every position along the columns, except in the vicinity of the heater in test TBT500, where halite would precipitate because of the extremely low water content. The modelling work of the LOT A2 experiment performed by Salas et al. (2014) also showed that chloride salts did not precipitate anywhere in the bentonite, despite the fact that the incoming water contained some chloride.

On the other hand, the dissolution processes in the most saturated parts of the bentonite were probably fast and equilibrium was reached quickly and maintained, as the similarity of water and ion contents for the two tests in the $5 \mathrm{~cm}$ closest to the hydration surface, seems to indicate. Gypsum dissolution was observed in the peripheral parts of the buffer in the TBT field test and in the A2 parcel of the LOT test ( $\AA$ kesson et al., 2012; Olsson \& Karnland, 2012).

The amounts of carbonate and bicarbonate in the pore water were less than found initially in both tests all along the columns, decreasing towards the heater (Fig. 11). The much smaller amount in the shorter test could have been caused by an initial process of carbonate precipitation triggered perhaps by the decrease in solubility of carbonates such as calcite with temperature. Carbonate precipitation would predominate near the heater, and in fact the XRD analyses showed an increase in calcite particularly at $3 \mathrm{~cm}$ from the heater. Because of the increase in water content with time, some of these newly formed carbonates could eventually dissolve, leading to the increase in alkalinity observed in test TBT1500 with respect to test TBT500.

A clear, overall decrease in the cation exchange capacity was observed in the two tests, more pronounced towards the heater. The same was observed in the samples retrieved from the Prototype test and analysed by Dohrmann \& Kaufhold (2014), although analyses of the same samples performed by Olsson and Karnland (2011) found no significant changes or trends in the CEC. The decrease in CEC was not observed in post-mortem analyses of the TBT field test or in the A2 parcel of the LOT test. In the laboratory $\mathrm{TH}$ tests the exchangeable $\mathrm{Na}^{+}$ions seemed to have been replaced by $\mathrm{Ca}^{2+}$ and $\mathrm{Mg}^{2+}$ in the hot zone. In the TBT field test the exchangeable $\mathrm{Na}$ was replaced by $\mathrm{Ca}$ in the warmest parts, but the amount of exchangeable $\mathrm{Mg}$ decreased with respect to the original, particularly nearer the heater ( $\AA$ kesson et al., 2012). The replacement of $\mathrm{Na}$ by $\mathrm{Ca}$ and $\mathrm{Mg}$ in the 
exchange complex was also observed in the heater contact in the Prototype test (Dohrmann \& Kaufhold, 2014) and in the hot blocks of the LOTA2 and A0 tests (Karnland et al., 2009, 2011). In the Prototype test a small but general loss in exchangeable $\mathrm{Mg}$ relative to the reference concentration was observed, with a slight increase towards the contact with the heater (Olsson et al., 2012; Dohrmann \& Kaufhold, 2014).

The ionic balance of the two tests is summarized in Table 2. In the shorter test, the amount of soluble and exchangeable $\mathrm{Mg}$ decreased, which could be related to dolomite precipitation (justifying the decrease in alkalinity) and to the observed increase in $\mathrm{Mg}$ in the octahedral sheet of the smectite. Over time, the soluble $\mathrm{Mg}$ content increased, which could be related to its release from the exchangeable complex and to the dissolution of carbonates indicated by the change in trend of alkalinity, which was greater in test TBT1500.

The amount of soluble $\mathrm{Ca}$ decreased in the shorter test with respect to the original material, which could be related to its increase in the exchangeable complex and to the initial precipitation of carbonates triggered by the temperature increase and associated with the decrease in alkalinity. The amount of soluble and exchangeable $\mathrm{Ca}$ increased over time, and the cause must have been the dissolution of carbonates and sulfates. The latter (probably gypsum) would be responsible for the increase in soluble sulfate in both tests.

The decrease in amount of $\mathrm{Na}$ and $\mathrm{K}$ in the exchangeable complex would be related to their increase as soluble species. Although the alkalinity decreased considerably in the shorter test - probably in relation to the precipitation of mineral phases the solubility of which decreases with temperature - it increased over time. This recovery would be related to the dissolution of some of the precipitated species activated by the increase in water content.

Because there was no input of chloride with the hydration water, the soluble chloride must be an exchangeable anion or come from a non-soluble mineral phase.

\section{SUMMARY AND CONCLUSIONS}

Columns of compacted bentonite were tested in thermo-hydraulic cells for two different periods of time, 17 and 50 months. The heater at the bottom of the cells was set to $140^{\circ} \mathrm{C}$ while deionized water was supplied through the top surface of the columns. Comparison of the results obtained in the post-mortem analyses of the bentonite allows some conclusions to be drawn about the evolution of the mineralogy and geochemistry of the bentonite: (1) the smectite content decreased and the amount of $\mathrm{Mg}$ in the octahedral sheet of the smectite increased over time, particularly towards the heater. The amount of interstratified illite increased towards the hydration area, more noticeably in the longer test, probably as a consequence of the colloidal dissolution of the smectite layers. (2) The calculated colloid concentration increased with the water content of the bentonite and over time, probably as a consequence of the continuous reduction in the pore-water ionic strength. (3) The increase in temperature triggered the precipitation of mineral phases the solubility of which decreases with temperature, such as carbonates, particularly near the heater. The increase in water content caused by the progressive hydration provoked the dissolution of salts (gypsum) as well as in some cases their advective transport and precipitation in drier zones. The pore water evolved from $\mathrm{Na}$ bicarbonate type in the original material to $\mathrm{Na}$ sulfate type in the hydrated areas and to Na-chloride type near the heater because of the low degree of water saturation. (4) Overall, the CEC decreased in the two tests, particularly towards the heater, where exchangeable $\mathrm{Na}$ was replaced by $\mathrm{Ca}$ and $\mathrm{Mg}$. Although the exchangeable $\mathrm{Mg}$ decreased in the shorter test, its content increased again over time.

When extrapolating these data to real repository conditions, the experimental constraints of this type of test must be taken into account. In particular, the fact that deionized water - rather than groundwater - was used for saturation and that evaporation through the base of the cell took place, which made desiccation more intense than in the real case.

From the point of view of the mineralogical and geochemical studies - for which the information comes from post-mortem analyses - the relevance of performing tests of different durations has been highlighted. Because a clear evolution over time of barrier geochemistry has been observed, the results from field or laboratory tests must be evaluated taking into account the particular moment in the transient repository evolution to which they relate.

\section{ACKNOWLEDGEMENTS}

The research leading to these results received funding from ENRESA (Spanish Agency for Nuclear Waste Management) and the European Atomic Energy Community's Seventh Framework Programme (FP7/ 2007-2011) under Grant Agreement $n^{\circ} 249681$, the PEBS project. J.M. Barcala, R. Campos, J. Aroz, F.J. 
Romero, A.M. Fernández, A. Garralón, L. Sánchez, A. Escribano and L. Gutiérrez-Nebot (CIEMAT) collaborated in the laboratory tests which were all performed in CIEMAT laboratories.

\section{REFERENCES}

Åkesson M. (2012) Temperature Buffer Test. Final report. SKB Technical Report TR-12-04. Svensk Kärnbränslehantering AB, Stockholm, 50 pp.

Åkesson M., Olsson S., Dueck A., Nilsson U., Karnland O., Kiviranta L., Kumpulainen S. \& Lindén J. (2012) Temperature Buffer Test. Hydro-mechanical and chemical/mineralogical characterizations. SKB P12-06, Svensk Kärnbränslehantering AB, Stockholm, $89 \mathrm{pp}$.

Appelo C.A.J. (2015) Principles, caveats and improvements in databases for calculating hydrogeochemical reactions in saline waters from 0 to $200^{\circ} \mathrm{C}$ and 1 to $1000 \mathrm{~atm}$. Applied Geochemistry, 55, 62-71.

Dohrmann R. \& Kaufhold S. (2014) Cation exchange and mineral reactions observed in MX 80 buffer samples of the Prototype repository in situ experiment in Äspö, Sweden. Clays and Clay Minerals, 62, 357-373.

Dueck A., Johannesson L.E., Kristensson O., Olsson S., Sjöland A. (2011) Hydro-mechanical and chemicalmineralogical analyses of the bentonite buffer from a full-scale field experiment simulating a high-level waste repository. Clays and Clay Minerals, 59, 595-607.

Fernández A.M. \& Villar M.V. (2010) Geochemical behaviour of a bentonite barrier in the laboratory after up to 8 years of heating and hydration. Applied Geochemistry, 25, 809-824.

Gómez-Espina R. \& Villar M.V. (2010a) Geochemical and mineralogical changes in compacted $M X-80$ bentonite submitted to heat and water gradients. Informes Técnicos CIEMAT 1199. Madrid, 33 pp.

Gómez-Espina R. \& Villar M.V. (2010b) Geochemical and mineralogical changes in compacted MX-80 bentonite submitted to heat and water gradients. Applied Clay Science, 47, 400-408.

Gómez-Espina R. \& Villar M.V. (2013) Modificaciones en la bentonita MX-80 compactada sometida a tratamiento termo-hidráulico. Informe Técnico CIEMAT 1290, Madrid, 85 pp.

Gómez-Espina R. \& Villar M.V. (2015) Effects of heat and humidity gradients on MX-80 bentonite geochemistry and mineralogy. Applied Clay Science, 109-110, 39-48.

Grim R.E. \& Kulbicki E. (1961) Montmorillonite: High temperature reactions and classification. American Mineralogist, 46, 1329-1369.

Karnland O. \& Birgesson M. (2006) Montmorillonite stability - with special respect to KBS-3 conditions.
SKB Technical Report TR-06-11. Svensk Kärnbränslehantering $\mathrm{AB}$, Stockholm, $39 \mathrm{pp}$.

Karnland O., Olsson S., Dueck A., Birgesson M., Nilsson U., Hernan-Hakansson T., Pedersen K., Nilsson S., Eriksen T.E. \& Rosborg B. (2009) Long term test of buffer material at the Äspö HRL, LOT Project. Final report on the A2 test parcel. SKB Technical Report TR-09-29. Svensk Kärnbränslehantering AB, Stockholm, 296 pp.

Karnland O., Olsson S., Sandén T., Fälth V., Jansson M., Eriksen T.E., Svärdström K., Rosborg B. \& Muurinen A. (2011) Long term test of buffer material at the Äspö HRL, LOT Project. Final report on the A0 test parcel. SKB Technical Report TR-09-31. Svensk Kärnbränslehantering AB, Stockholm, 123 pp.

Meier L.P. \& Kahr G. (1999) Determination of the exchange capacity (CEC) of clay minerals using the complexes of copper(II) ion with triethylenetetramine and tetraethylenepentamine. Clays and Clay Minerals, 47, 386-388.

Moore D.M. \& Reynolds R.C. (1997) X-ray Diffraction and the Identification and Analysis of Clay Minerals, 2nd edition. Oxford University Press, New York, 332 pp.

Olsson S. \& Karnland O. (2011) Mineralogical and chemical characteristics of the bentonite in the A2 test parcel of the LOT field experiments at Äspö HRL, Sweden. Physics and Chemistry of the Earth, 36, 1545-1553.

Olsson S., Jensen V., Johannesson L.E., Hanse E., Karnland O., Kumpulainen S., Kiviranta L., Svensson D., Hansen S. \& Lindén J. (2013) Prototype Repository. Hydromechanical, chemical and mineralogical characterization of the buffer and tunnel backfill material from the outer section of the Prototype Repository. SKB Technical Report TR-13-21. Svensk Kärnbränslehantering $\mathrm{AB}$, Stockholm, 168 pp.

Parkhurst D.L. \& Appelo C.A.J. (1999) Users guide to PHREEQC (Version 2) - a computer program for speciation, batch reactions, one dimensional transport and inverse geochemical calculations. Water Resources Investigations Report 99-4259, US Geological Survey.

Reynolds R.C. (1980) Interstratified clay minerals. Pp. 249-303 in: Crystal Structures of Clay Minerals and Their X-ray Identification (G.W. Brindley and G. Brown, editors). Monograph 5, Mineralogical Society, London.

Salas J., Sena C. \& Arcos D. (2014) Hydrogeochemical evolution of the bentonite buffer in a KBS-3 repository for radioactive waste. Reactive transport modeling of the LOT A2 experiment. Applied Clay Science, 101, 521-532.

Sandén T., Goudarzi R., de Combarieu M., Åkesson M. \& Hökmark H. (2007) Temperature buffer test - design, instrumentation and measurements. Physics and Chemistry of the Earth, 32, 77-92. 
Villar M.V., Sánchez M. \& Gens A. (2008) Behaviour of a bentonite barrier in the laboratory: Experimental results up to 8 years and numerical simulation. Physics and Chemistry of the Earth, 33, S476-S485.

Villar M.V., Gómez-Espina R., Gutiérrez-Nebot L., Campos R. \& Barrios I. (2012) Physical changes in MX-80 bentonite saturated under thermal gradient.
ANDRA 5th International Meeting Clays in Natural and Engineered Barriers for Radioactive Waste Confinement, Montpellier, October 2012. Abstracts, pp 312-313, AP/PTO/10.

Wersin P., Johnson L.H. \& McKinley I.G. (2007) Performance of the bentonite barrier at temperatures beyond $100^{\circ} \mathrm{C}$ : A critical review. Physics and Chemistry of the Earth, 32, 780-788. 